\title{
Kognitivno opterećenje i eksterna reprezentacija pravila rješavanja problema "hanojskih tornjeva"
}

\author{
Nermin Đapo, Mirna Marković, Ratko Đokić \\ Odsjek za psihologiju, Filozofski fakultet Univerziteta u Sarajevu, Bosna i Hercegovina
}

\section{Sažetak}

Rješavanje problema često predstavlja situaciju u kojoj su postavljeni preveliki zahtjevi na resurse radnog pamćenja. U situaciji rješavanja novih kompleksnih problema broj problemskih elemenata koji se trebaju simultano procesirati i njihova interaktivnost mogu nadići raspoloživi kapacitet radnog pamćenja. S obzirom na to da doprinosi smanjenju kognitivnog opterećenja, eksterna reprezentacija može značajno pridonijeti efikasnijem rješavanju problema. Cilj je našeg istraživanja bio ispitati efekte eksterne reprezentacije na uspješnost rješavanja i kognitivno opterećenje problema "hanojskih tornjeva". U istraživanju je sudjelovalo 30 studenata Odsjeka za psihologiju Filozofskog fakulteta u Sarajevu. Sudionici su rješavali tri izomorfne varijante problema "hanojskih tornjeva", preuzete iz istraživanja Zhanga i Normana (1994). Različitim je varijantama problema variran broj eksternih pravila njegova rješavanja. Kognitivno je opterećenje utvrđeno Upitnikom kognitivnog opterećenja (Paas, 1992).

Rezultati istraživanja upućuju na to da se efikasnost rješavanja problema povećava s brojem eksterno reprezentiranih pravila, što je u skladu s rezultatima dobivenim u istraživanju Zhanga i Normana (1994). Nadalje, utvrđeno je da eksterna pravila pridonose smanjenju procjene uloženog mentalnog napora i povećanju razumijevanja problema. Procjena je težine problema bila podjednaka za sve tri varijante problema.

Rezultati našeg istraživanja potvrđuju nalaze prethodnih istraživanja da korištenje eksternih reprezentacija pridonosi efikasnijem rješavanju kompleksnih problema. Također, eksterna reprezentacija smanjuje subjektivni doživljaj kognitivnog opterećenja. Međutim, generičke strategije izazivaju visoko kognitivno opterećenje per se, što uvjetuje visok doživljaj težine problema, bez obzira na objektivnu težinu problema.

Ključne riječi: teorija kognitivnog opterećenja, rješavanje problema, reprezentacija pravila, kognitivno opterećenje

\section{Uvod}

Prema teoriji kognitivnog opterećenja (TKO) (Sweller, 1988; Sweller, Ayres i Kalyuga, 2011; Sweller, van Merriënboer i Paas, 1998) težina problema ovisi o njegovoj kompleksnosti i razini interaktivnosti elemenata problema (Sweller i Chandler, 1991, 1994). Problemi koje odlikuje visoka razina interaktivnosti

Nermin Đapo, Odsjek za psihologiju, Filozofski fakultet u Sarajevu, Franje Račkog 1, 71000 Sarajevo, Bosna i Hercegovina. E-pošta: nermin.djapo@ff.unsa.ba 
elemenata mogu biti zahtjevni jer uvjetuju visoko kognitivno opterećenje radnog pamćenja. Multimodalno reprezentiranje informacija jedan je od načina smanjenja kognitivnog opterećenja (Mayer, 2001; Mayer i Moreno, 2003). Reprezentacije mogu biti interne, kada se nalaze u radnom pamćenju, ili eksterne, kada su date $\mathrm{u}$ eksternoj formi zadatka. Zhang i Norman (1994) predložili su teorijski okvir distribucije internih i eksternih reprezentacija, prema kojem je apstraktni prostor problema rezultat simbiotičke veze između internih reprezentacija, koje aktiviraju kognitivne procese i eksternih reprezentacija, koje aktiviraju perceptivne procese. Eksterne reprezentacije mogu izravno aktivirati perceptivne operacije i kognitivne aktivnosti te ih stoga nije potrebno re-reprezentirati u formi interne reprezentacije (Zhang, 1997). S obzirom na to da doprinosi smanjenju kognitivnog opterećenja, eksterna reprezentacija može značajno pridonijeti učinkovitijem učenju i rješavanju problema.

U istraživanjima efekata multimodalne reprezentacije na učenje i rješavanje problema uglavnom su korišteni konceptualni (npr. Chandler i Sweller, 1991) i proceduralni problemi (npr. Mayer i Anderson, 1991; Mayer i Sims, 1994) specifične domene, kao što su matematika i druge znanosti. Relativno su rijetka istraživanja u kojima su se koristili problemi iz domene općega znanja čije se rješavanje temelji na generičkim strategijama. Ovakvi problemi u pravilu uvjetuju visoko kognitvno opterećenje, naročito ako se proces rješavanja temelji na većem broju pravila. Cilj je našeg istraživanja bio ispitati efekte eksterne reprezentacije na učinkovitost i kognitivno opterećenje u rješavanju problema "hanojskih tornjeva".

\section{Teorija kognitivnog opterećenja}

Prema TKO-u, arhitekturu ljudske kognicije čine spremnici radnog i dugoročnog pamćenja. Radno je pamćenje ograničenog kapaciteta pohrane i vremena zadržavanja informacija, što uvjetuje otežanu simultanu asimilaciju višestrukih novih informacija (Sweller, 2005). Međutim, ograničenje se radnog pamćenja značajno smanjuje pri procesiraju informacija iz dugoročnog pamćenja. $U$ dugoročnom su pamćenju informacije organizirane $u$ formi kognitivnih shema. Sheme smanjuju opterećenje radnog pamćenja jer jednom kada su formirane i automatizirane, u radnom se pamćenju mogu održavati uz malo kognitivnog napora. Ako shema nije usvojena, svi elementi problema moraju se držati u radnom pamćenju kao odvojene jedinice, što može dovesti do visokih zahtijeva koji nadilaze kapacitet radnog pamćenja. Resursi radnog pamćenja potrebni za učenje određenog materijala (Sweller i Chandler, 1994) ili izvedbu određenog zadatka (Sweller i sur., 1998) predstavljaju kognitivno opterećenje. Lagani i uvježbani zadaci imaju nisko kognitivno opterećenje jer su za njihovu izvedbu potrebni mali kognitivni resursi, dok teški i neuvježbani zadaci imaju visoko kognitivno opterećenje jer zahtijevaju visoke kognitivne resurse. Iznos se resursa radnog pamćenja koje osoba dodjeljuje procesima učenja ili izvedbe zadatka naziva mentalni napor. Posljedica je visokog opterećenja nedovoljan kapacitet radnog pamćenja za formiranje shema, što s druge 
strane uvjetuje neefikasno učenje i rješavanje problema. TKO definira tri tipa kognitivnog opterećenja: intrinzično (engl. intrinsic), irelevantno (engl. extraneous) i relevantno (engl. germane) opterećenje. Intrinzično opterećenje nastaje zbog kompleksnosti materijala koji je potrebno procesirati. U potpunosti je određeno brojem i interaktivnošću kognitivnih elemenata (simbola, koncepata, procedura, pravila) koji se simultano obrađuju u radnom pamćenju (Sweller i sur., 2011). Irelevantno je opterećenje nepotrebno opterećenje uvjetovano dizajnom i organizacijom materijala (Sweller i sur., 2011), tj. formatom i načinom prezentacije informacija. Zahtijeva dodatni mentalni napor zbog nepotrebnih kognitivnih aktivnosti koje ne doprinose usvajanju ili automatizaciji shema (Sweller, 2005). Kognitivno opterećenje koje dovodi do formiranja i automatizacije shema, a time i do učenja i rješavanja problema, naziva se relevantno opterećenje. Prema TKO-u, ukupno je kognitivno opterećenje zbroj intrinzičnog, irelevantnog i relevantnog kognitivnog opterećenja. Zahtjevi uvjetovani intrinzičnim $i$ irelevantnim opterećenjem koji nadilaze raspoložive resurse radnog pamćenja za posljedicu mogu imati nemogućnost kognitivnog sustava da procesira potrebne informacije.

U novije se vrijeme TKO razmatra iz evolucijske perspektive. Prema Sweller i sur. (2011) i Sweller i Sweller (2006) strukture i funkcije kognitivne arhitekture rezultat su prirodne selekcije i kulturalnog nasljeđa koji su doveli do formiranja biološki primarnog i biološki sekundarnog znanja (Geary, 2007). Kroz nebrojene generacije naših predaka evoluiralo je biološki primarno znanje, koje je univerzalno i koje se usvaja bez eksplicitnog podučavanja, lako i automatski. Tako, govor, prepoznavanje lica i fizičkih objekata, planiranje, donošenje odluka pripadaju ovoj kategoriji znanja. Kulturalno okruženje dovodi do formiranja biološki sekundarnog znanja, čije usvajanje zahtijeva ulaganje napora u sklopu formalnih i neformalnih oblika podučavanja. Čitanje, računanje, korištenje računala, poznavanje koncepata i formula iz statistike ili kinetike, sposobnost rješavanje konceptualnih ili proceduralnih problema specifičnog domena primjeri su sekundarnog znanja. Generičke strategije rješavanja problema, kao što je analiza sredstvo - cilj i drugi slični heuristici, spadaju u biološki primarno znanje (Geary, 2007). Prema TKO-u, generičke strategije ne pružaju učinkovit načini usvajanja znanja i vještina, posebno kada se radi o početnicima. Sweller (1988) je detaljno elaborirao efekte korištenja strategije sredstvo - cilj na učenje i rješavanje problema u domenu fizike i pokazao kako ova strategija dovodi do značajnog povećanja mentalnog opterećenja. Naime, strategija sredstvo - cilj snažno opterećuje kapacitet radnog pamćenja jer podrazumijeva simultano razmatranje trenutnog stanja, ciljnog stanja, odnosa između trenutnog i ciljnog stanja, kao i odnosa između operatora (Sweller, 1988). Stoga je učenje kroz rješavanje problema neefikasno jer je usvajanje shema spriječeno. Postupci učenja u kojima se koriste primjeri riješenih problema (pogledati Cooper i Sweller, 1987) ili od cilja slobodni problemi (engl. goal free problems) (pogledati Ayres, 1993), smanjuju potrebu za pretragom problemskog prostora tijekom rješavanja problema, a time i opterećenje radnog pamćenja. Zapravo, TKO je djelomično nastao upravo kao teorijski odgovor na problem 
neefikasnosti generičkih strategija u podučavanju početnika, stoga se TKO uglavnom odnosi na sekundarno biološko znanje. U okviru teorije elaborirani su empirijski verificirani postupci podučavanja kojima se smanjuje nepotrebno kognitivno opterećenje i postiže efikasnije učenje i rješavanje problema.

U skorije se vrijeme javlja zanimanje istraživača za probleme iz opće domene u kojima se do rješenja dolazi kroz generičke strategije. Youssef, Ayres i Sweller (2012) pokazali su da biološki primarno znanje može biti važno za usvajanje biološki sekundarnog znanja, naročito u situacijama kompleksnih problema u kojima je problemski prostor velik, mnoge varijable nepoznate, a osoba ne posjeduje dovoljno razvijenu bazu znanja iz specifične domene. Zheng, Miller, Snelbecker i Cohen (2006) istraživali su učinkovitost multimedijalne reprezentacije u rješavanju analitičkih problema s više pravila. Uz opis su problemske situacije sudionicima prezentirana međusobno isključiva pravila koja su morala biti simultano procesirana. Na primjer, u zadatku kontrole zračnog prometa opisano je kako na aerodrom slijeće pet aviona (u grafičkom prikazu označenih različitim bojama) te da će kontrolor leta voditi avione do njihovih izlaza, pri čemu je potrebno zadovoljiti pet uvjeta (na primjer, plavi avion i ljubičasti avion ne mogu biti parkirani jedan pored drugoga). Uz svaki su problem navedena pitanja s ponuđenim odgovorima. Dobiveni rezultati upućuju na to da interaktivne grafičke prezentacije pospješuje rješavanje problema i smanjuje kognitivno opterećenje u odnosu na ne-interaktivni uvjet. U drugom su istraživanju Zheng i Cookova (2011) koristeći iste probleme, ovaj put prezentirane u grafičkoj i tekstualnoj formi, utvrdili da grafička (ne-interaktivna) reprezentacija smanjuje kognitivno opterećenje.

Rezultati navedenih istraživanja jasno upućuju na to da izvor visokoga kognitivnog opterećenja kod kompleksnih problema nije samo strategija rješavanja problema već i način reprezentacije elemenata problema.

\section{Reprezentacija problema}

Rješavanje problema počinje reprezentacijom problema, odnosno konstruiranjem mentalnog modela problema koji sadrži informacije o ciljnom stanju problema, objektima i njihovoj međusobnoj interakciji, potrebnim operacijama te preprekama koje stoje na putu od početnog do ciljnog stanja (Novick i Bassok, 2005). U brojnim je istraživanjima pokazano da različiti aspekti konteksta problema mogu imati snažan utjecaj na reprezentacije problema. Rezultati istraživanja Simon i Hayes (1976), Kotovsky i Simon (1990) i Kotovsky, Hayes i Simon (1985) pokazali su da različiti opisi operatora dvaju izomorfnih problema dovode do različitih reprezentacija, što s druge strane ima snažan efekt na težinu problema. Navedeni su autori konstruirali dvije varijante problema "hanojskih tornjeva" - "prijenos" i "promjena".

U klasičnoj verziji problema "hanojskih tornjeva", prikazanoj na Slici 1., na jednom se od tri štapića (1, 2 i 3 ) nalaze tri diska (A, B i C). U početnom su stanju 
diskovi složeni na štapiću 1, od najmanjeg (disk A) na vrhu do najvećeg (disk C) na dnu. Zadatak je premjestiti diskove sa štapića 1 na štapić 3 prema sljedećim pravilima: (a) odjednom se može pomjeriti samo jedan disk, (b) potez se sastoji od pomicanja samo gornjeg diska; i (c) veći disk se ne smije postaviti na manji. Raspored diskova u ciljnom stanju problema treba biti isti kao u početnom: na vrhu se treba nalaziti najmanji (disk A), a na dnu najveći disk (disk C). Problem je riješen kada se postigne ciljna konfiguracija diskova.

Slika 1. Problem "hanojskih tornjeva"

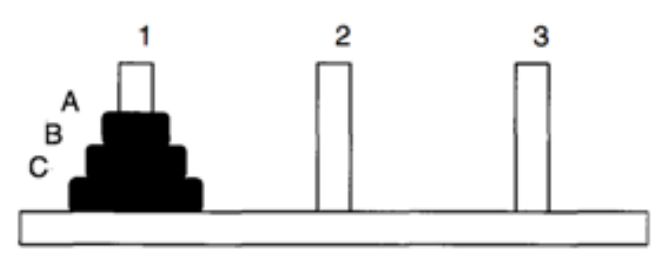

Početno stanje

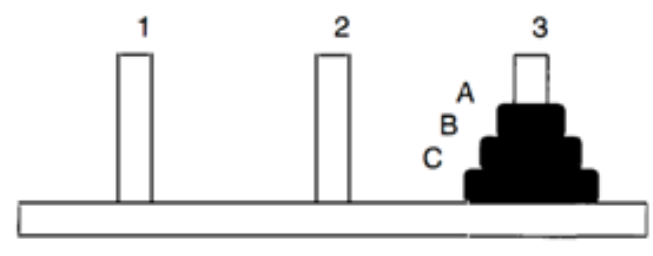

Ciljno stanje

Umjesto štapića i diskova u navedenim su istraživanjima elementi problema bili čudovišta i globusi triju različitih veličina: male, srednje i velike. U obje navedene varijante problema, varijanti "prijenosa" i "promjene", inicijalna je pozicija bila ista: malo čudovište drži veliki globus, čudovište srednje veličine drži mali globus dok veliko čudovište drži globus srednje veličine. Zadatak je sudionika bio da veličinu globusa usklade s veličinom čudovišta koje ga drži. Jedina je razlika između dvije varijante zadatka bila u reprezentaciji operatora. U varijanti "prijenosa" globusi su se mogli premještati poštujući sljedeća tri pravila: (a) u jednom se potezu može premjestiti samo jedan globus; (b) ako čudovište drži više globusa, samo se najveći globus može premjestiti; (c) globus se ne može premjestiti čudovištu koje drži veći globus. U varijanti "promjene" operator je podrazumijevao promjenu veličine čudovišta prema sljedećim pravilima: (a) u jednom se potezu može promijeniti veličina samo jednog čudovišta; (b) ako su dva čudovišta iste veličine, samo čudovištu koje drži veći globus može se promijeniti veličina; (c) čudovište ne može promijeniti veličinu tako da postane iste veličine kao ono čudovište koje drži veći globus. S obzirom na to da su problemi strukturalno identični, mogu se riješiti korištenjem istih sekvenci poteza u istom problemskom prostoru. Međutim, autori navode da su sudionici, rukovodeći se opisom danim u instrukciji, konstruirali različite reperezentacije za svaku od dvije varijante problema. Različite su reprezentacije dovele i do različitih rezultata: za rješavanje varijante "prijenosa" 
sudionicima je u prosjeku trebalo približno 14 minuta, dok je vrijeme rješavanja varijante "promjena" iznosilo 29 minuta. Dobiveni rezultati jasno pokazuju da reprezentacija problema ima snažan efekt na težinu problema (Hayes i Simon, 1977). Autori su zaključili da je lakoća usvajanja pravila i/ ili njihova primjena ovisila o konzistentnosti pravila i svakodnevnog znanja. Problemi koji uključuju pravila kompatibilna sa svakodnevnim znanjem bit će lakši od problema koji sadrže pravila koja su manje kompatibilna sa svakodnevnim znanjem. Osim toga, u nekim su problemima pravila i ograničenja fizički uočljiva i čine tzv. eksternu memoriju, što je također moglo pridonijeti efikasnosti rješavanja.

\section{Interna i eksterna reprezentacija}

Teorijski okvir interne i eksterne reprezentacije Zhanga i Normana (1994) relativno je novija istraživačka perspektiva kojom se nastoji odgovoriti na pitanje na koji način osoba konstruira reprezentacije problema i kako različite forme reprezentacije utječu na rješavanje problema. Eksternu reprezentaciju čine znanja i strukture iz okoline, kao što su fizički simboli, objekti ili njihove dimenzije, eksterna pravila, ograničenja ili relacije utjelovljene u fizičkoj konfiguraciji (npr. spacijalne relacije pisanih znamenki, fizička ograničenja abakusa itd). Informacije u eksternoj reprezentaciji mogu biti prikupljene, analizirane i procesirane u perceptivnom sustavu, premda konceptualno znanje interne reprezentacije nekad može pospješiti ili inhibirati perceptivne procese. S druge strane, internu reprezentaciju čine znanja i strukture pamćenja, pohranjene $u$ formi propozicija, shema ili produkcijskih pravila. Informacije interne reprezentacije prizivaju se iz pamćenja pomoću kognitivnih procesa, premda i znakovi eksterne reprezentacije mogu pokrenuti proces pretraživanja. Razlika između interne i eksterne reprezentacije jasno se može vidjeti na primjeru množenja dvaju brojeva pomoću papira i olovke. Interne su reprezentacije značenja pojedinih simbola, tablice zbrajanja i množenja, aritmetičke operacije i slično, koje je potrebno prizivati iz dugoročnog pamćenja. Eksterne su reprezentacije oblici i pozicije simbola, spacijalne relacije parcijalnih proizvoda $\mathrm{i}$ slično. S obzirom na to da su date u samom problemu nije ih potrebno prizivati iz pamćenja. Obje forme reprezentacija imaju podjednako važan doprinos u reprezentacijskom sistemu. Interna reprezentacija formira interni prostor reprezentacija, dok eksterna reprezentacija formira eksterni prostor reprezentacija. Interni i eksterni prostor reprezentacija zajedno čine distribuirani prostor reprezentacije, odnosno reprezentaciju apstraktnog prostora zadatka, koja opisuje strukturu i svojstva zadatka.

Prema Zhang (1997), sve do devedesetih godina prošlog stoljeća zanemarivala se važnost razlikovanja interne i eksterne reprezentacije. Fokus istraživačke pozornosti bio je gotovo isključivo usmjeren na interne reprezentacije. Kada su eksterne reprezentacije bile predmetom istraživanja, često su izjednačavane $\mathrm{s}$ internom reprezentacijom ili su smatrane njezinom komponentom. Međutim, eksterne reprezentacije nisu jednostavni ulazi i poticaji internom umu, niti samo 
pomoć pamćenju (Zhang, 1997). Eksterne reprezentacije mogu biti intrinzični dio zadatka koji vodi, ograničava pa čak i određuje obrazac kognitivnog ponašanja i način na koji um funkcionira. U cilju ispitivanja načina na koje različite distribucije reprezentacija pravila utječu na težinu problema, Zhang i Norman (1994) su kreirali niz izomorfnih verzija problema hanojski tornjevi. U jednom od eksperimenata sudionici su rješavali tri problema: (a) "konobar i naranača", (b) "konobar i prstenasti uštipak" i (c) "konobar i kava". U Tablici 1. dati su shematski opisi problema, broj internih i eksternih pravila i navedena interna pravila.

Tablica 1. Opisi problema korištenih u istraživanju Zhang i Norman (1994)

\begin{tabular}{|c|c|c|c|}
\hline & Konobar i naranča & $\begin{array}{c}\text { Konobar i } \\
\text { prstenasti uštipak }\end{array}$ & Konobar i kava \\
\hline \multicolumn{4}{|l|}{$\begin{array}{l}\text { Shematski } \\
\text { prikaz } \\
\text { problema }\end{array}$} \\
\hline $\begin{array}{l}\text { Broj eksternih } \\
\text { pravila }\end{array}$ & 0 & 1 & 2 \\
\hline $\begin{array}{l}\text { Broj internih } \\
\text { pravila }\end{array}$ & 3 & 2 & 1 \\
\hline \multirow{3}{*}{ Interna pravila } & $\begin{array}{l}\text { U jednom se potezu } \\
\text { može prebaciti samo } \\
\text { jedna naranča. }\end{array}$ & $\begin{array}{l}\text { U jednom se potezu } \\
\text { može prebaciti samo } \\
\text { jedan uštipak. }\end{array}$ & \multirow{3}{*}{$\begin{array}{l}\text { U jednom se } \\
\text { potezu može } \\
\text { prebaciti samo } \\
\text { jedna šalica. }\end{array}$} \\
\hline & $\begin{array}{l}\text { Naranča se može } \\
\text { prebaciti na drugi } \\
\text { tanjur samo ako će } \\
\text { na tom tanjuru biti } \\
\text { najveća. }\end{array}$ & $\begin{array}{l}\text { Uštipak se može } \\
\text { prebaciti na drugi stupić } \\
\text { samo ako će na tom } \\
\text { stupiću biti najveći. }\end{array}$ & \\
\hline & $\begin{array}{l}\text { Samo se najveća } \\
\text { naranča na tanjuru } \\
\text { može prebaciti na } \\
\text { drugi tanjur. }\end{array}$ & & \\
\hline
\end{tabular}

Pravila su svih triju problema bila identična: (a) samo se jedan predmet može pomaknuti u jednom potezu, (b) može se pomaknuti samo onaj predmet koji će kada se premjesti biti najveći i (c) s bilo koje pozicije može se pomaknuti samo najveći predmet. Jedina razlika između problema bila je u distribuciji reprezentacije pravila. U zadatku "konobar i naranče" sva su pravila interna (na primjer, pravilo prema kojem se manja naranča ne može naći pored veće naranče), dok je u problemu 
"konobar i kava" jedno pravilo interno, a dva eksterna (na primjer, pravilo prema kojem nije moguće manju šalicu kave postaviti iznad veće jer bi upala u veću šalicu). Rezultati istraživanja upućuju na to da težina problema raste s povećanjem broja internih pravila (tj. opada s brojem eksternih pravila): vrijeme rješavanja, broj poteza i broj nedozvoljenih poteza rastu s brojem internih pravila (tj. opadaju s brojem eksternih pravila). Zhang i Norman (1994) su dobivene rezultate interpretirali pomoću teorijskog okvira distribuirane reprezentacije. Eksterna se pravila mogu provjeravati kroz percepcijsku inspekciju, za razliku od internih pravila, koja se moraju provjeravati mentalno. Tako zadatak postaje teži jer procesiranje internih pravila zahtijeva veće resurse radnog pamćenja. Osim toga, procesiranje internih pravila može interferirati s drugim procesima u rješavanju problema; s druge strane, eksterna pravila mogu pomoći u učinkovitijem korištenju rekurzivne strategije čije je otkrivanje teže ako su pravila interna (Zhang i Norman, 1994).

\section{Eksterna reprezentacija u rješavanju problema i kognitivno opterećenje}

Implikacije su teorijskog okvira interne i eksterne reprezentacije kongruentne s TKO-om: eksterna reprezentacija smanjuje opterećenje radnog pamćenja, a time i kognitivno opterećenje. Ova tvrdnja postaje očigledna ako istraživanje Zhanga i Normana (1994) sagledamo iz ugla TKO-a.

Kod izomorfnih zadataka promjena reprezentacije pravila ne dovodi do promjene strukture problemskog prostora. U terminima TKO-a, broj elemenata koji čine strukturu problema u izomorfnim zadacima jednak je bez obzira na distribuciju pravila jer su ista ciljna stanja problema, isti skup pravila, jednak broj objekata koji se pomjeraju, objekti dijele isto svojstvo (npr. veličine: veliki, srednji i mali) i iste pozicije (npr. lijeva, srednja i desna). Interna se pravila moraju provjeravati mentalno što zahtijeva veće resurse radnog pamćenja i mogućnost interferiranja $\mathrm{s}$ drugim procesima, kao što je na primjer planiranje narednog poteza (Zhang i Norman, 1994). S obzirom na to da su razlike u veličini objekata očigledne te da fizički odnos između dva elementa nameće (ne)mogućnost poteza (npr. manju šalicu kave nije moguće postaviti iznad veće jer bi u tom slučaju upala u veću), eksterna se pravila mogu provjeriti perceptivnom inspekcijom, pa se stoga procesiraju gotovo automatski. Osim toga, eksterna pravila ne zahtijevaju njihovo zapamćivanje jer su utjelovljena u problemskoj situaciji te ih nije potrebno eksplicitno navoditi. Eksterna pravila, u terminima TKO-a, smanjuju interaktivnost između elemenata, a time i intrinzično opterećenje. Međutim, promjenom se distribucije reprezentacije pravila ne mijenja strategija rješavanja problema: bez obzira na distribuciju pravila, početnik se najčešće koristi strategijom sredstvo - cilj. Osoba rješava problem tako da vidi cilj koji treba postići i pokušava smanjiti razliku između cilja (rješenja) i svoje trenutne pozicije u problemskom prostoru. Ovakva strategija često rezultira slijepim ulicama, a osoba koja rješava problem mora simultano razmatrati nekoliko elemenata problema (trenutno stanje, ciljno stanje, relacije između pravila itd.). Kako je već navedeno, Sweller (1988) smatra da je strategija sredstvo - cilj neefikasna jer je 
kapacitet za kognitivno procesiranje toliko opterećen da ostavlja malo prostora za usvajanje shema, čak i kada se problem riješi. Stoga, eksterna reprezentacija ne dovodi do smanjenja kognitivnog opterećenja uvjetovanog strategijom rješavanja problema.

U cilju ispitivanja efekata eksterne reprezentacije pravila na efikasnost rješavanja problema provedeno je istraživanje $\mathrm{u}$ kojem je repliciran postupak korišten u istraživanju Zhanga i Normana (1994). Očekujemo da u našem istraživanju repliciramo rezultate dobivene u izvornom istraživanju. Dodatno, kako bi ispitali efekte eksterne reprezentacije pravila problema na kognitivno opterećenje, nakon rješavanja će svakog problema odgovarajućom procedurom biti utvrđeno kognitivno opterećenje. S obzirom na to da eksterna reprezentacija smanjuje interaktivnost elemenata, a time i intrinzično opterećenje, očekujemo da će povećanjem broja eksternih pravila doći do smanjenja kognitivnog opterećenja.

\section{Metoda}

\section{Sudionici}

U istraživanju je sudjelovalo $N=30$ sudionika ( 25 žena; prosječna dob $M=19.5$ godina, $S D=0.89$ ). Svi su sudionici bili studenti Odsjeka za psihologiju Filozofskog fakulteta u Sarajevu. U istraživanju su sudjelovali dobrovoljno, a kao naknadu za sudjelovanje dobili su parcijalni kredit za polaganje studijskog kolegija.

\section{Pribor i instrumentarij}

\section{Problemi}

U istraživanju su korištene tri izomorfne varijante problema "hanojskih tornjeva", preuzete iz istraživanja Zhanga i Normana (1994). Tri su korištena problema: "konobar i kolač" (u izvornom je obliku naziv problema bio "konobar i naranče"), "konobar i prstenasti uštipak" i "konobar i kava". U Tablici 1. dati su opisi problema.

Elementi problema konstruirani su od priručnog materijala: tri drvene pločice različitih dimenzija (mala, srednja i velika) i tri plastična tanjura za problem "konobar i kolač"; tri drvena prstena različitih dimenzija (mali, srednji i veliki) i drvena podloga na kojoj su postavljena tri stupića za problem "konobar i prstenasti uštipak"; tri kutije različitih veličina (mala, srednja i velika), koje su na jednoj strani bile otvorene i tri plastična tanjura za problem "konobar i kava". Na posebnim su karticama prikazana početna i ciljna stanja za svaki problem. Uz svaki je zadatak pripremljen odgovarajući tekst koji opisuje hipotetsku situaciju u kojoj konobar uslužuje tri gosta kolačima, prstenastim uštipcima ili kavom, a koje treba rasporediti prema određenim pravilima. Na primjer, u problemu "konobar i kava" opis je glasio: 
"Tri gosta sjede za šankom i svaki je naručio šalicu kave. Ispred svakog je gosta tanjurić na kojem se poslužuje kava. Gost koji sjedi lijevo naručio je kavu u srednje veličine, gost u sredini kavu u maloj šalici, a gost koji sjedi desno naručio je kavu u velikoj šalici. Konobar je u svaku šalicu nalio kavu te sve tri šalice poredao od najmanje do najveće, jednu iznad druge i postavio ispred gosta koji sjedi lijevo, kao što je prikazano na dijagramu 1 (Slika 2.). Zadatak je konobara premjestiti šalice kave tako da svaka bude poslužena gostu kojem pripada, kao što je prikazano na dijagramu 2 (Slika 2.). Pri tome može upotrebljavati samo jednu ruku, a ni jedna šalica ne smije biti spuštena na stol niti se kava smije prosuti po tanjuriću ili stolu".

Slika 2. Početna i završna pozicija problema "konobara i kave"

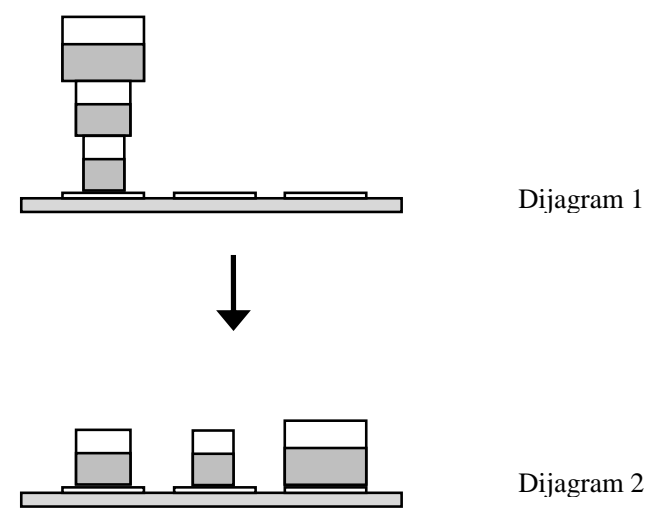

$\mathrm{Za}$ svaki je problem utvrđeno vrijeme rješavanja, broj poteza $\mathrm{i}$ broj nedozvoljenih poteza (na primjer, potez kojim se manja šalica pokuša staviti na veću šalicu).

Mjere kognitivnog opterećenja

Procjena je kognitivnog opterećenja utvrđena pomoću modificirane verzije Upitnika kognitivnog opterećenja (Paas, 1992). Upitnik se sastoji od tri čestice koje mjere subjektivnu procjenu uloženoga mentalnog napora, težine problema i razumijevanja problema (npr. mentalni je napor utvrđen česticom koja je glasila: "Tijekom rješavanja problema uložio sam:"). Za svaku je česticu korištena skala Likertova tipa od devet stupnjeva (npr. za procjenu mentalnog napora vrijednost 1 označavala je "vrlo, vrlo malo mentalnog napora", a vrijednost 9 "vrlo, vrlo mnogo mentalnog napora"). 


\section{Dizajn}

Na Slici 3. dat je prikaz problemskog prostora problema "hanojskih tornjeva", koji sadrži 27 mogućih rasporeda (stanja) tri diska na tri štapića. Linijama između konfiguracija prikazane su transformacije iz jednog stanja u drugo. U našem su istraživanju S1, S2 i S3 početne pozicije, a Z1, Z2 i Z3 završne pozicije. Početne i završne pozicije nisu randomizirane, tj. za svakog sudionika prvi, drugi i treći problem počinju redom na pozicijama S1, S2 i S3, a završavaju na pozicijama $Z 1$, Z2 i Z3.

Svaki je sudionik rješavao svaki od tri problema u nizu, jedan za drugim. Redoslijed je problema unaprijed određen pomoću latinskog kvadrata. U istraživanju je korišten djelomični nacrt u kojem je uravnoteženje postignuto jednokratnom primjenom svih mogućih rasporeda eksperimentalnih uvjeta (tj. problema). Svaki je zadatak slijedio i prethodio drugom zadatku jednak broj puta. S obzirom na to da su korištena tri zadatka, broj je mogućih rasporeda šest. Sudionici su slučajnim odabirom raspoređeni u jedan od šest rasporeda. U svakom je rasporedu bilo pet sudionika.

Slika 3. Problemski prostor problema "hanojskih tornjeva"

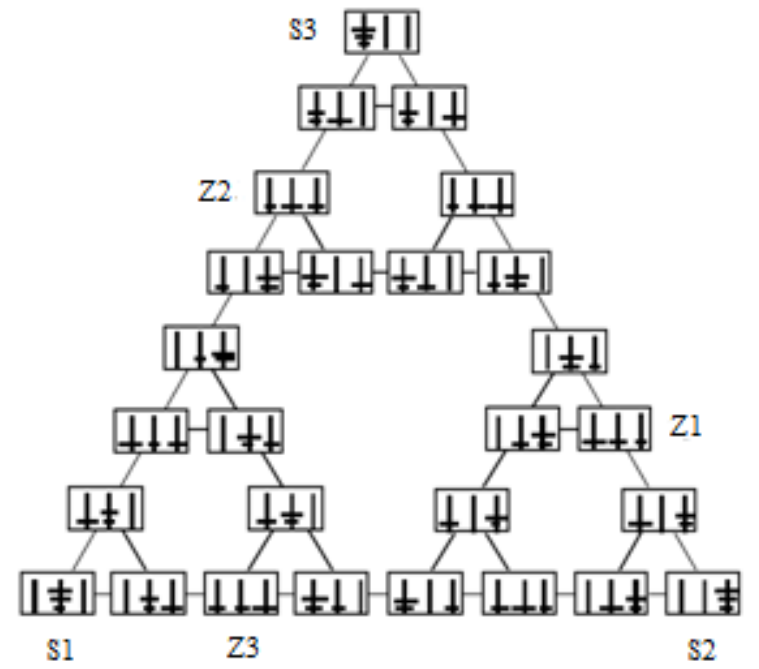

\section{Postupak}

Istraživanje je provedeno $\mathrm{u}$ prostoriji $\mathrm{u}$ kojoj su uz sudionika bili eksperimentator $\mathrm{i}$ asistent eksperimentatora. Eksperimentator je najprije pročitao opis problema s pravilima i slikama početne i ciljne pozicije, a sudionik je pratio tekst upute napisane na papiru. Zatim je od sudionika traženo da ponovi pravila dva puta zaredom bez greške. U protivnom, sudionik je ponovno čitao uputu, sve dok ne bi 
točno ponovio pravila dva puta zaredom. Nakon toga je na radni stol postavljen pribor i slike početne i završne pozicije, uz instrukciju sudioniku da pristupi rješavanju problema. Ako je sudionik napravio nedozvoljen potez, bio je upozoren uz napomenu da element vrati na prethodnu poziciju. Asistent eksperimentatora bilježio je broj poteza i broj nedozvoljenih poteza, dok je eksperimentator mjerio vrijeme rješavanja problema ručnom digitalnom štopericom. U protokol je bilježeno vrijeme rješavanja problema, broj poteza i broj nedozvoljenih poteza. Nakon što bi riješio problem, sudionik je ispunjavao Upitnik kognitivnog opterećenja. Ista procedura ponovljena je za dva preostala zadatka.

\section{Rezultati}

U cilju analize prikupljenih podataka provedena je jednostavna analiza varijance za ponovljena mjerenja. Post hoc analize provedene su uz Bonferronijevu korekciju pripadajućih vrijednosti $p$.

\section{Efikasnost rješavanja problema}

Efikasnost rješavanja problema određena je vremenom rješavanja problema, brojem poteza i brojem nedozvoljenih poteza. Na Slici 4. prikazane su aritmetičke sredine mjera efikasnosti s obzirom na broj eksternih pravila u zadatku.

Sudionicima je u prosjeku trebalo znatno više vremena da riješe problem bez eksternih pravila $(M=5.20 \mathrm{~min}, S D=4.60)$ u odnosu na probleme s jednim $(M=1.97$, $S D=1.30)$ i dva $(M=1.95, S D=2.00)$ eksterna pravila. Utvrđene razlike u prosječnim vremenima rješavanja problema su statistički značajne $F(2,48)=12.10, p=.0001$, $\left({ }_{p} \eta^{2}=0.294\right)$. Post hoc testom utvrđeno je da se prosječno vrijeme rješavanja problema bez eksternih pravila statistički značajno razlikuje od vremena rješavanja problema $\mathrm{s}$ jednim eksternim pravilom $(p=.002)$ kao i problema s dva eksterna pravila $(p=.003)$. Razlika između prosječnih vremena rješavanja problema s jednim i dva eksterna pravila nije statistički značajna $(p=1)$.

Prosječan je broj poteza koji su bili potrebni za rješavanje problema bez eksternih pravila znatno veći $(M=23.6, S D=18.62)$ u odnosu na broj poteza potrebnih za rješavanje problema s jednim $(M=12.87, S D=4.91)$ i dva $(M=13.53, S D=8.10)$ eksterna pravila. Utvrđene su razlike statistički značajne, $F(2,48)=7.60, p=.001$ $\left(\eta^{2}=0.208\right)$. Post hoc testovi pokazuju da je prosječni broj poteza za problem bez eksternih pravila statistički značajno različit od broja poteza za problem $\mathrm{s}$ jednim eksternim pravilom $(p=.02)$ kao i od broja poteza za problem s dva eksterna pravila $(p=.03)$. Nije utvrđena statistički značajna razlika između prosječnog broja poteza rješavanja problema $\mathrm{s}$ jednim i s dva eksterna pravila $(p=1)$. 
Đapo, N., Marković, M., Đokić, R.:

Kognitivno opterećenje i reprezentacija pravila rješavanja problema

Slika 4. Aritmetičke sredine i 95\% granice pouzdanosti mjera efikasnosti za probleme bez eksternih pravila te s jednim i dva eksterna pravila
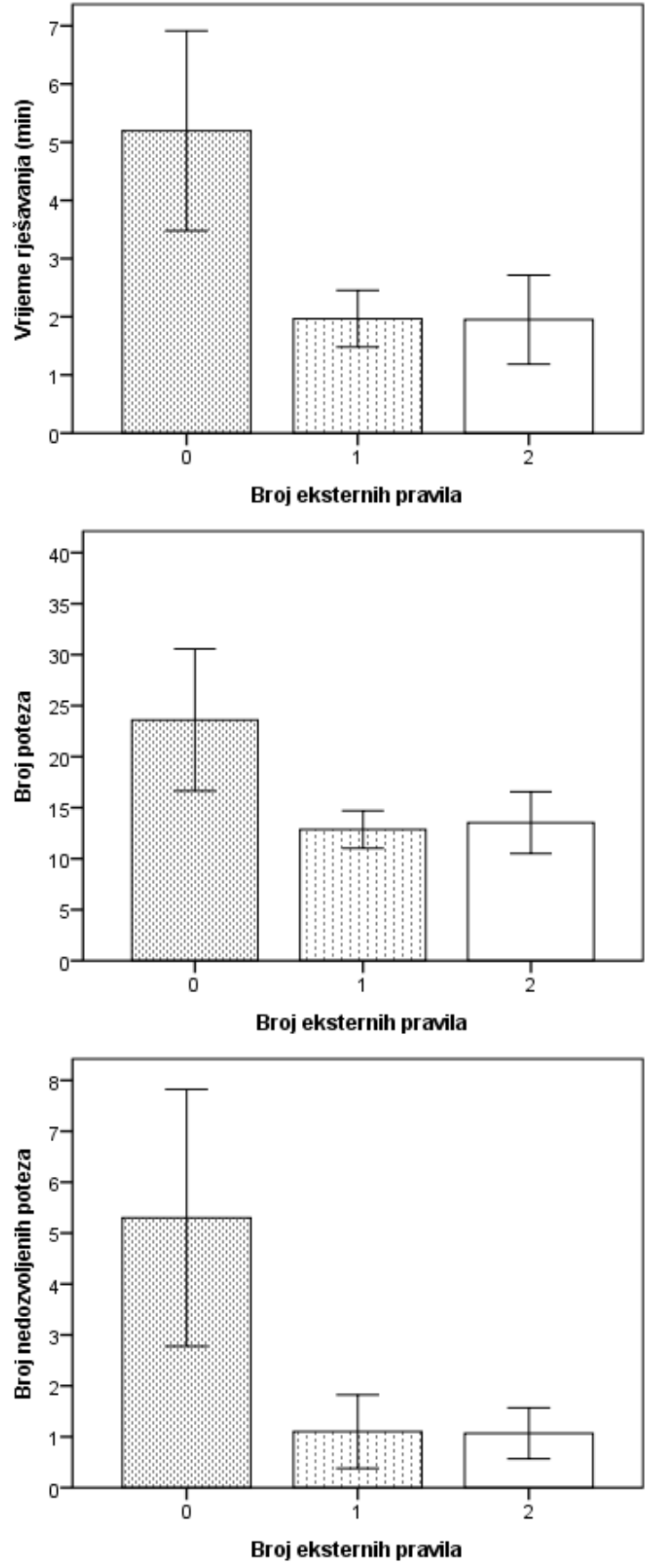
Prosječan je broj nedozvoljenih poteza najveći za probleme bez eksternih pravila $(M=5.30, S D=6.76)$, te znatno manji za problem s jednim $(M=1.10, S D=1.93)$ i dva interna pravila $(M=1.07, S D=1.34)$. Razlike u broju nedozvoljenih poteza su statistički značajne, $F(2,48)=11.73, p=.0001,\left(p \eta^{2}=0.288\right)$. Post hoc testom utvrđen je isti obrazac rezultata kao i u prethodna dva slučaja. Razlika između prosječnog broja nedozvoljenih poteza kod rješavanja problema bez eksternih pravila i s jednim eksternim pravilom je statistički značajna $(p=.003)$ kao i između problema bez eksternih pravila i s dva eksterna pravila $(p=.005)$. Razlika između prosječnog broja nedozvoljenih poteza u problemima s jednim i dva eksterna pravila nije statistički značajna $(p=1)$.

\section{Subjektivna procjena kognitivnog opterećenja}

Na Slici 5. prikazane su aritmetičke sredine procjene mentalnog napora, težine i razumijevanja s obzirom na broj eksternih pravila u zadatku.

Procjena mentalnog napora uloženog u rješavanje problema najveća je za problem bez eksternih pravila $(M=5.73, S D=1.74)$, zatim s jednim $(M=4.83$, $S D=1.98)$ te s dva eksterna pravila $(M=4.73, S D=2.02)$. Utvrđene su razlike statistički značajne, $F(2,29)=3.16, p=.05\left({ }_{p} \eta^{2}=0.098\right)$. Post hoc testom utvrđena je statistički značajna razlika između procjene uloženog mentalnog napora za problem bez eksternih pravila i problem s dva eksterna pravila. Razlika između problema bez eksternih pravila i jednim eksternim pravilom nije statistički značajna $(p=.15)$, kao niti između mentalnog napora za problem s jednim i dva eksterna pravila $(p=1)$.

Procjena je težine problema najveća za problem bez eksternih pravila $(M=4.57$, $S D=2.30)$, dok je nešto manja za problem s jednim $(M=3.57, S D=1.83)$ i dva eksterna pravila $(M=3.67, S D=1.97)$. Nije utvrđena statistički značajna razlika između prosječnih procjena težine problema, $F(2,29)=2.45, p=.10\left({ }_{p} \eta^{2}=0.078\right)$.

Sudionici procjenjuju da je problem bez eksternih pravila bilo najteže razumjeti $(M=3.90, S D=2.04)$, dok su za razumijevanje nešto lakši bili problem s jednim $(M=3.07, S D=2.21)$ i dva eksterna pravila $(M=2.50, S D=1.53)$. Utvrđene su razlike statistički značajne $F(2,29)=4.04, p=.02 \quad\left({ }_{p} \eta^{2}=0.122\right)$. Post hoc test pokazuje statistički značajnu razliku u razumijevanju problema bez eksternih pravila i s dva eksterna pravila $(p=.006)$. Između prosječnih vrijednosti razumijevanja problema bez eksternih pravila i problema s jednim eksternim pravilom nije utvrđena statistički značajna razlika $(p=.46)$, kao ni između problema s jednim i dva eksterna pravila $(p=.79)$. 
Đapo, N., Marković, M., Đokić, R.:

Kognitivno opterećenje i reprezentacija pravila rješavanja problema

Slika 5. Aritmetičke sredine i 95\% granice pouzdanosti procjena mentalnog napora, težine $i$ razumijevanja za probleme bez eksternih pravila te s jednim i dva eksterna pravila
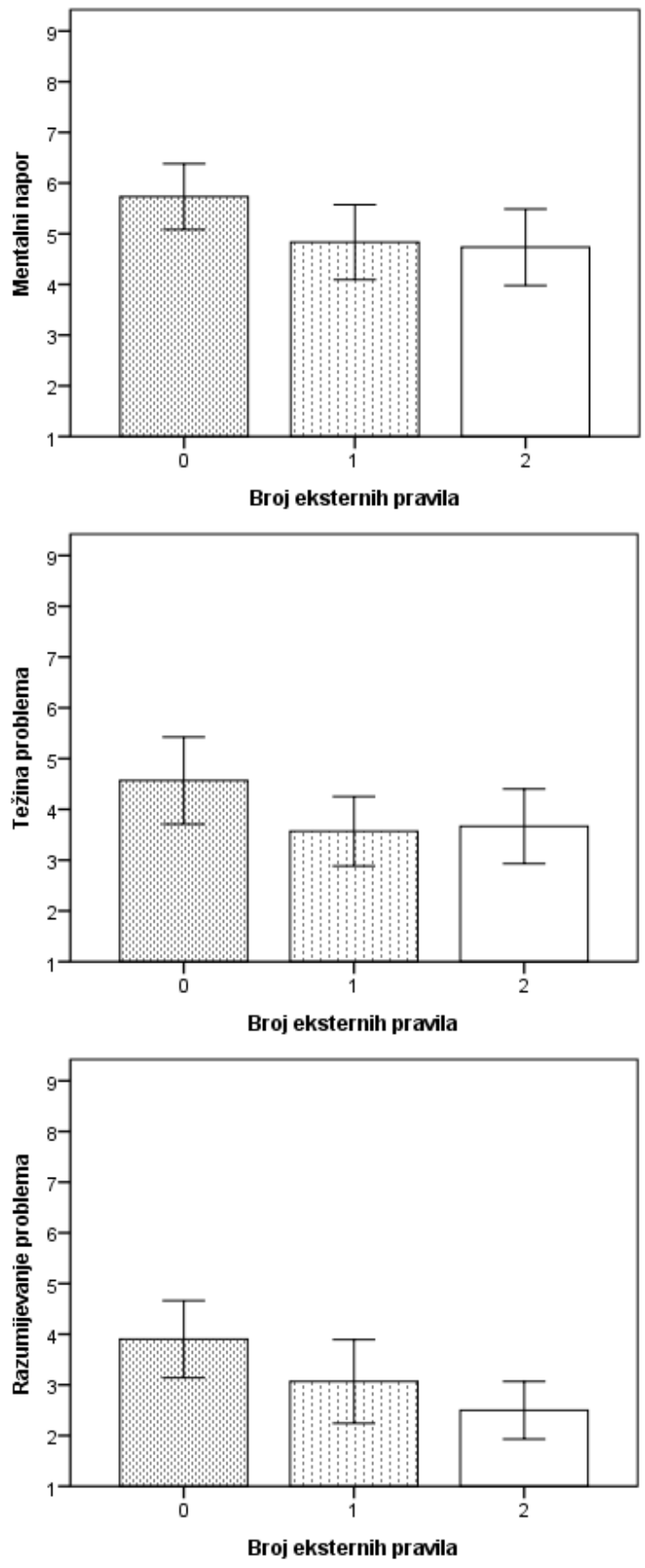


\section{Rasprava}

$\mathrm{U}$ istraživanjima u kojima su pokazani pozitivni efekti eksterne reprezentacije na kognitivno opterećenje uglavnom su korišteni konceptualni i proceduralni problemi iz specifične domene (Chandler i Sweller, 1991; Mayer i Anderson, 1992; Mayer i Moreno, 1998; Mayer i Sims, 1994). Relativno su rijetka istraživanja u kojima su se koristili problemi iz domene općega znanja, čije se rješavanje temelji na generičkim strategijama. Ovakvi problemi u pravilu uvjetuju visoko kognitivno opterećenje, naročito ako se proces rješavanja temelji na većem broju pravila. Cilj je našeg istraživanja bio ispitati efekte eksterne reprezentacije na uspješnost rješavanja i kognitivno opterećenje problema "hanojskih tornjeva".

Rezultati istraživanja upućuju na to da se efikasnost rješavanja problema povećava s brojem eksterno reprezentiranih pravila: vrijeme rješavanja, broj poteza i broj nedozvoljenih poteza znatno su veći za problem bez eksternih pravila u odnosu na problem s jednim ili dva eksterna pravila. Rezultati dobiveni u našem istraživanju u skladu su s rezultatima dobivenim u istraživanju Zhanga i Normana (1994). Autori su utvrdili da je prosječno vrijeme rješavanja problema, broj poteza i broj nedozvoljenih poteza bio najveći za problem s tri interna pravila dok nisu utvrđene razlike između problema s dva i jednim internim pravilom. Prema Hambrick i Engle (2003), uspješnost rješavanja mnogih problema zavisi od sposobnosti održavanja relevantnih informacija u visoko aktiviranom i dostupnom stanju posredstvom kontrolirane pažnje, kao i od sposobnosti inhibiranja irelevantnih ili distraktibilnih informacija. Problem "hanojskih tornjeva" zahtjevan je kognitivni zadatak s obzirom na potrebu održavanja pravila i podciljeva u stanju visokog aktiviteta i dostupnosti te inhibiranja neučinkovitih poteza, dok samo otkriće rješenja može zavisiti od sposobnosti aktiviranja i održavanja informacija kroz višestruke, neuspješne pokušaje. Procesiranje internih pravila zahtijeva više resursa radnog pamćenja, što može interferirati s drugim procesima važnim u rješavanju problema. Stoga je vrijeme rješavanja i broj poteza veći što je broj internih pravila veći. S obzirom na to da se eksterna pravila mogu provjeravati perceptualnom inspekcijom prije nego što se napravi potez, broj nedozvoljenih poteza opada u funkciji broja eksternih pravila. Kontrolirana pažnja kao funkcija radnog pamćenja omogućava ne samo održavanje elemenata problema u aktivnom stanju nego i supresiju ili inhibiciju irelevantnih informacija koje ometaju proces rješavanja problema. Veći broj nedozvoljenih poteza, koji predstavljaju slijepe ulice, u uvjetima bez eksternih pravila upućuje na smanjenu funkciju inhibicije. Eksterna pravila olakšavaju funkciju kontrolirane pažnje, tj. smanjuju zahtjeve prema radnom pamćenju, pa je efikasnost rješavanja problema s eksternim pravilima veća u usporedbi s efikasnošću rješavanja problema bez eksternih pravila. U našem je istraživanju pokazano da je dovoljno jedno eksterno pravilo pa da se efikasnost rješavanja problema značajno poveća.

Drugi je cilj istraživanja bio provjeriti je li eksterna pravila pridonose reduciranju subjektivnog doživljaja kognitivnog opterećena. Utvrđeno je da eksterna 
pravila pridonose smanjenju procjene uloženoga mentalnog napora. Prema Paas, Tuovinen, Tabbers i van Gerven (2003, str. 64) mentalni je napor "aspekt kognitivnog opterećenja koji se odnosi na kognitivni kapacitet koji se trenutno izdvaja kako bi se prilagodilo zahtjevima nametnutim zadatkom". Stoga mentalni napor može odražavati aktualno kognitivno opterećenje. Rezultati dobiveni u našem istraživanju upućuju na to da su se sudionici prilagođavali zahtjevima problema određenom distribucijom pravila. Eksterna pravila pridonose smanjenju intrinzičnog opterećenja, a time i manjem mentalnom naporu. O sličnim efektima izvještavaju Paas i sur. (1994) i Gimino (2002) prema kojima su subjektivne skale procjene mentalnog ulaganja osjetljive na relativno malu promjenu u kognitivnom opterećenju izazvanu variranjem intrinzičnog opterećenja. Međutim, rezultati našeg istraživanja upućuju na to da je samoprocjena uloženog mentalnog napora osjetljiva na razlike između problema s najmanjim i problema s najvećim brojem eksternih pravila, ali ne i na razlike između problema koji su sličniji po broju eksternih pravila. Moguće je objašnjenje ovakvog nalaza da odnos između interaktivnosti elemenata i samoprocjena mentalnog napora nije linearan, te se osjetljivost subjektivne procjene mentalnog napora na probleme koji se razlikuju u interaktivnosti elemenata manifestira kada je ta razlika dovoljno velika i doseže određeni prag.

Veći broj eksternih pravila dovodi do manjeg kognitivnog opterećenja, pa bi procjena težine problema trebala biti manja za probleme s većim brojem eksternih pravila. Međutim, rezultati našeg istraživanja pokazuju da su sudionici podjednako teškim procjenjivali sva tri problema, bez obzira na broj eksternih pravila. Ovaj rezultat nije bio očekivan $\mathrm{s}$ obzirom na to da se ocjena težine materijala izravno odnosi na nametnuto kognitivno opterećenje (Kalyuga, Chandler i Sweller, 1999). Marcus, Cooper i Sweller (1996) pokazali su da subjektivna procjena težine značajno varira s razinom interaktivnosti elemenata zadatka, dok je Ayres (2006) utvrdio da ova mjera može detektirati varijacije $u$ interaktivnosti elemenata zadatka. Rezultat dobiven u našem istraživanju može se objasniti prirodom primijenjenog problema. Naime, sudionici nisu imali formirane sheme rješenja problema te su stoga koristili kognitivno zahtjevne strategije rješavanja problema. Bez formiranih shema osoba koja rješava problem najčešće koristi strategiju sredstvo - cilj ili pristup pokušaja i pogreške. To postavlja visoke zahtjeve pred radno pamćenje s obzirom na nužnost simultanog održavanja aktivnim brojnih elemenata problema. Sama po sebi, strategija sredstvo - cilj uvjetuje visoko ekstrinzično opterećenje jer svaka irelevantna kognitivna aktivnost, koja ne vodi ka formiranju i automatizaciji shema, dovodi do visokoga kognitivnog opterećenja (Sweller, 2005; Sweller i Chandler, 1994).

Rezultati našeg istraživanja pokazuju da eksterna pravila pridonose boljem subjektivnom osjećaju razumijevanja problema. Prema Schnotz i Kürschner (2007), razumijevanje je proces konstruiranja mentalne reprezentacije u radnom pamćenju. Slično navode i Marcus i sur. (1996) prema kojima do razumijevanja dolazi kada se u radnom pamćenju simultano procesiraju sve relevantne informacije. Materijal je 
teško razumljiv ako sadrži velik broj interaktivnih elemenata koji se ne mogu simultano držati u radnom pamćenju (Sweller i sur., 1998). Ovo potvrđuju i rezultati našeg istraživanja. Naime, veći broj pravila koje najprije treba pohraniti u dugoročno pamćenje, a zatim tijekom rješavanja problema simultano držati aktivnim u radnom pamćenju, uvjetuje manji stupanj razumijevanja problema. Eksterna pravila smanjuju interaktivnost elemenata problema i pridonose većem doživljaju razumijevanja. U skladu je s ovim i nalaz prema kojem je najveći broj nedozvoljenih poteza napravljen u problemu u kojem nije bilo eksternih pravila.

Istovremeno, osnovno se ograničenje našeg istraživanja može prepoznati u metodologiji mjerenja kognitivnog opterećenja. Tehnike mjerenja kognitivnog opterećenja korištenjem skala procjene temelje se na pretpostavci da ljudi imaju uvid u vlastite kognitivne procese, kao i sposobnost izvještavanja o iznosu uloženog mentalnog napora. Međutim, subjektivne procjene kognitivnog opterećenja često dovode do različitih, čak i kontradiktornih rezultata (pogledati de Jong, 2010). Ipak, primijenjeni Upitnik kognitivnog opterećenja ima prihvatljivu konvergentnu, konstruktnu i divergentnu validnosti (Gimino, 2002; Paas i sur., 1994) te se i dalje široko koristi (Paas i sur., 2003). Međutim, u budućim je istraživanjima potrebno koristiti direktne mjere kognitivnog opterećenja. Dodatno, i sama struktura našeg uzorka, koji uglavnom čine studentice, ograničava mogućnost generalizacije dobivenih rezultata. Zanimljivo je da u okviru TKO-a spolne razlike ne predstavljaju relevantan istraživački problem. $\mathrm{U}$ budućim je istraživanjima potrebno ispitati eventualne efekte spola, posebno s obzirom na evolucijsku nadogradnju teorije.

\section{Zaključak}

Rješavanje problema često predstavlja situaciju u kojoj su postavljeni preveliki zahtjevi na upravljačke i resurse pažnje radnog pamćenja. Prilikom rješavanja novih kompleksnih problema radno je pamćenje suočeno s određenim ograničenjima. Broj problemskih elemenata koje je potrebno simultano procesirati i njihova interaktivnost mogu nadići raspoloživ kapacitet radnog pamćenja. Korištenje eksterne reprezentacije elemenata problema jedan je od načina efikasnog upravljanja kognitivnim resursima. Kako navodi Simon (1978, str. 153): "Rješavanje problema jednostavno znači njegovu reprezentaciju tako da se rješenje učini vidljivim". Promjena reprezentacije elemenata problema, pri čemu formalna struktura zadatka ostaje ista, može drastično smanjiti kognitivno opterećenje. Rezultati našeg istraživanja potvrđuju nalaze prethodnih istraživanja da korištenje eksternih reprezentacija pridonosi učinkovitijem rješavanju kompleksnih problema. Također, eksterna reprezentacija smanjuje subjektivni doživljaj kognitivnog opterećenja. Međutim, generičke strategije izazivaju visoko kognitivno opterećenje per se, što uvjetuje izražen doživljaj težine problema, bez obzira na njegovu objektivnu težinu. Buduća istraživanja u kojima bi se kognitivno opterećenje mjerilo direktnim tehnikama i u kojima bi se ispitivao transfer potpomognut eksternalizacijom 
reprezentacija bila bi od velike važnosti za razumijevanje kako konceptualnih, tako i praktičnih implikacija TKO-a.

\section{Literatura}

Ayres, P. (1993). Why goal-free problems can facilitate learning. Contemporary Educational Psychology, 18, 376-381.

Ayres, P. (2006). Using subjective measures to detect variations of intrinsic cognitive load within problems. Learning and Instruction, 16, 389-400.

Chandler, P. i Sweller, J. (1991). Cognitive load theory and the format of instruction. Cognition and Instruction, 8, 293-332.

Cooper, G. i Sweller, J. (1987). Effects of schema acquisition and rule automation on mathematical problem-solving transfer. Journal of Educational Psychology, 79(4), 347362.

de Jong, T. (2010). Cognitive load theory, educational research, and instructional design: Some food for thought. Instructional Science, 38, 105-134.

Geary, D. (2007). Educating the evolved mind: Conceptual foundations for an evolutionary educational psychology. U: J.S. Carlson i J.R. Levin (Ur.), Psychological perspectives on contemporary educational issues (str. 1-100). Greenwich, CT: Information Age Publishing.

Gimino, A. (2002). Students' investment of mental effort. Paper presented at the annual meeting of the American Educational Research Association, New Orleans, LA.

Hambrick, D.Z. i Engle, R.W. (2003). The role of working memory in problem solving. U: J.E. Davidson i R.J. Sternberg (Ur.), The psychology of problem solving (str. 176-206). Cambridge; Cambridge University Press.

Hayes, J.R. i Simon, H.A. (1977). Psychological differences among problem isomorphs. U: N.J. Castellan, D.B. Pisoni i G.R. Potts (Ur.), Cognitive theory (Vol. 2, str. 21-44). Hillsdale, NJ: Erlbaum.

Kalyuga, S., Chandler, P. i Sweller, J. (1999). Managing split-attention and redundancy in multimedia instruction. Applied Cognitive Psychology, 13, 351-371.

Kotovsky, K., Hayes, J.R. i Simon, H.A. (1985). Why are some problems hard?: Evidence from Tower of Hanoi. Cognitive Psychology, 17, 248-294.

Kotovsky, K. i Simon, H.A. (1990). What makes some problems really hard: Explorations in the problem space of difficulty. Cognitive Psychology, 22, 143-183.

Marcus, N., Cooper, M. i Sweller, J. (1996). Understanding instruction. Journal of Educational Psychology, 88(1), 49-63.

Mayer, R.E. (2001). Multimedia learning. New York: Cambridge University Press.

Mayer, R.E. i Anderson, R.B. (1991). Animations need narrations: An experimental test of a dual-coding hypothesis. Journal of Educational Psychology, 83, 484-490. 
Mayer, R.E. i Anderson, R.B. (1992). The instructive animation: Helping students build connections between words and pictures in multimedia learning. Journal of Educational Psychology, 84, 444-452.

Mayer, R.E. i Moreno, R. (1998). A split-attention effect in multimedia learning: Evidence for dual processing systems in working memory. Journal of Educational Psychology, 90, 312-320.

Mayer, R.E. i Moreno, R. (2003). Nine ways to reduce cognitive load in multimedia learning. Educational Psychology, 38, 43-52.

Mayer, R.E. i Sims, V.K. (1994). For whom is a picture worth a thousand words? Extensions of a dual-coding theory of multimedia learning. Journal of Educational Psychology, 84, 389-460.

Novick, L.R. i Bassok, M (2005). Problem solving. U: K.J.I. Holyoak i R.G. Morrison (Ur.), The Cambridge handbook of thinking and reasoning (str. 321-350). Cambridge University Press.

Paas, F. (1992). Training strategies for attaining transfer of problem-solving skill in statistics: A cognitive-load approach. Journal of Educational Psychology, 84, 429-434.

Paas, F., Tuovinen, J.E., Tabbers, H. i Gerven, P.W.M. (2003). Cognitive load measurement as a means to advance cognitive load theory. Educational Psychologist, 38(1), 63-71.

Paas, F., van Merriënboer, J.J.G. i Adam, J.J. (1994). Measurement of cognitive load in instructional research. Perceptual and Motor Skills, 79, 419-430.

Schnotz, W. i Kürschner, C. (2007). A reconsideration of Cognitive load theory. Educational Psychological Review, 19, 469-508.

Simon, H.A. i Hayes, J.R. (1976) The understanding process: Problem isomorphs. Cognitive Psychology, 8, 165-190.

Simon, D.P. (1978). Information processing theory of human problem solving. U: D. Estes (Ur.), Handbook of learning and cognitinve process (str. 271-296). Hillsdale, NJ: Lawrence Erlbaum Associates.

Sweller, J. (1988). Cognitive load during problem solving: Effects on learning. Cognitive Science, 12, 257-285.

Sweller, J. (2005). Implications of cognitive load theory for multimedia learning. U: R.E. Mayer (Ur.), The Cambridge handbook of multimedia learning (str. 19-30). New York: Cambridge University Press.

Sweller, J., Ayers, P. i Kalyuga, S. (2011). Cognitivne load theory. Springer, New York.

Sweller, J. i Chandler, P. (1991). Evidence for cognitive load theory. Cognition and Instruction, 8(4), 351-362.

Sweller, J. i Chandler, P. (1994). Why some material is difficult to learn. Cognition and Instruction, 12(3), 185-233.

Sweller, J. i Sweller, S. (2006). Natural information processing systems. Evolutionary Psychology, 4, 434- 458. 
Sweller, J., van Merriënboer, J.J.G. i Paas, F.G.W.C. (1998). Cognitive architecture and instructional design. Educational Psychology Review, 10, 251-296.

Youssef, A., Ayers, P. i Sweller, J. (2012). Using general problem-solving strategies to generate ideas in order to solve geography problems. Applied Cognitive Psychology, 26, 872-877.

Zhang, J. (1997). The nature of external representation in problem solving. Cognitive Science, 21(2), 179-217.

Zhang, J. i Norman, D. (1994). Representations in distributed cognitive tasks. Cognitive Science, 18(1), 87-122.

Zheng, R. i Cook, A. (2011). Solving complex problems: A convergent approach to cognitive load measurement. British Journal of Educational Technology, 43(2), 233-246.

Zheng, R., Miller, S., Snelbecker, G. i Cohen, I. (2006). Use of multimedia for problemsolving tasks. Journal of Technology, Instruction, Cognition and Learning, 3(1-2), 135 143.

\title{
Cognitive Load and External Representation of Tower of Hanoi Problem-Solving Rules
}

\begin{abstract}
Problem-solving often represents a highly demanding situation for working memory recourses. When dealing with new and complex problems, the number and interactivity of problem elements which could be processed simultaneously could exceed the available capacity of the working memory. External representation could significantly increase the effectiveness of problem-solving because they reduce the cognitive load. Our study was conducted with the aim to investigate the effects of external representation on solving success and cognitive load of Tower of Hanoi problems. The participants were 30 students of Department of Psychology, Faculty of Philosophy in Sarajevo. The participants solved three isomorphic variants of Tower of Hanoi problem taken from the Zhang and Norman (1994) study. With different variant, the number of external rules varied. Cognitive load was measured with the Questionnaire of cognitive load (Paas, 1992).

The results obtained in our research show that the efficiency of problem-solving increases with the number of external rules. This result is in accordance with results obtained in the Zhang and Norman (1994) study. External rules decrease subjective estimate of mental effort and increase the understanding of the problem. There are no differences in estimation of the difficulty of problems.

Results of our study confirm the findings of the previous study that the external representations contribute to effective problem-solving of the complex problem. In addition, external representations reduce cognitive load. Generic strategies impose a high cognitive load per se, which cause high estimate of problem difficulty, regardless of the objective difficulty of a problem.
\end{abstract}

Keywords: Cognitive load theory, problem-solving, representation of problem-solving rules, cognitive load 


\section{Carga cognitiva y representación externa de las reglas para resolver el problema de las torres de Hanói}

\section{Resumen}

Resolver un problema frecuentemente representa una situación que supone exigencias demasiado grandes para los recursos de la memoria de trabajo. En la situación de resolver los nuevos problemas complejos, el número de los elementos problemáticos que deberían procesarse simultáneamente y su interactividad podrían exceder la capacidad disponible de la memoria de trabajo. La representación externa puede contribuir significativamente a resolver el problema dado que contribuye a la reducción de la carga cognitiva. El objetivo de este trabajo fue examinar los efectos de la representación externa sobre la eficacia en cuanto a la resolución y la carga cognitiva de las torres de Hanói. En la investigación participaron 30 estudiantes del Departamento de Psicología de la Facultad de Filosofía y Letras de Sarajevo. Los participantes resolvían tres variantes isomorfas del problema de las torres de Hanói, tomadas de la investigación hecha por Zang y Norman (1994). A través de variantes diferentes del problema se ha variado el número de reglas externas para resolver el problema. La carga cognitiva se ha determinado a través del Cuestionario de Carga Cognitiva (Pass, 1992).

Los resultados de la investigación indican que la eficacia en resolver el problema aumenta con el número de las reglas externamente representadas, lo que corresponde a los resultados obtenidos en la investigación de Zhang y Norman (1994). Además, se ha determinado que las reglas exteriores contribuyen a la menor percepción del esfuerzo mental invertido y al mayor entendimiento del problema. La percepción del grado de dificultad del problema fue más o menos igual para todas las tres variantes del problema.

Los resultados de nuestra investigación confirman los hallazgos de las investigaciones previas que dicen que el uso de las representaciones externas contribuye a la resolución más eficaz de los problemas complejos. Además, representación externa reduce la percepción subjetiva de la carga cognitiva. Sin embargo, las estrategias genéricas causan carga cognitiva alta per se, lo que condiciona percepción de la dificultad alta del problema, independientemente de su dificultad objetiva.

Palabras claves: teoría de carga cognitiva, solución del problema, representación de reglas, carga cognitiva

Primljeno: 22.12.2014. 